\title{
Sterically hindered 5,15-tetraphenylbenzene-porphyrins: syntheses, structures, atropisomerism and photophysical properties
}

\author{
R V RAMANA REDDY, BIJU BASUMATARY, MUTHUCHAMY MURUGAVEL, \\ KARUNESH KESHAV, ADIKI RAJA SEKHAR and JEYARAMAN SANKAR*(1) \\ Department of Chemistry, Indian Institute of Science Education and Research Bhopal, Bhopal Bypass Road, \\ Bhauri, Bhopal 462 066, Madhya Pradesh, India \\ E-mail: sankar@iiserb.ac.in
}

MS received 20 March 2018; revised 26 April 2018; accepted 27 April 2018; published online 30 June 2018

\begin{abstract}
Tetraphenylbenzene (TPB) substituted porphyrin hybrids have been designed and synthesized. The meso-TPB-porphyrin hybrids exhibit two discrete atropisomers due to restricted rotation around $\mathrm{C}_{m e s o^{-}}$ $\mathrm{C}_{\mathrm{TPB}}$ bond. Both the atropisomers could be structurally characterized. The photophysical and electrochemical properties of the synthesized hybrids have been investigated with respect to tetraphenylporphyrin (TPP) and tetraphenylporphyrinatozinc(II) (ZnTPP). These hybrids exhibit reminiscent absorption and emission properties. Moreover, the redox potentials of the TPB conjugates are found to be sensitive to the meso-substituents as in the case of meso-aryl substituents.
\end{abstract}

Keywords. Porphyrin; atropisomer; tetraphenylbenzene.

\section{Introduction}

In the myriad of organic $\pi$-conjugated materials, $\pi$ extended porphyrins play a vital role because of their potential applications in the fields of photovoltaics, ${ }^{1}$ organic semiconductors, ${ }^{2}$ photodynamic therapy, ${ }^{3}$ and non-linear optics. ${ }^{4}$ Recently, interest has been increased towards designing porphyrins decorated with polycyclic aromatic hydrocarbons (PAHs) which results in promising candidates for organic electronic applications. ${ }^{5}$ The intense absorption of porphyrins is often confined to visible region. Porphyrins can be exploited to the fullest extent for various applications if their absorption can be bathochromically shifted towards NIR range. Typically, $\pi$-extension is associated with a bathochromic shift of the electronic absorption spectra of these compounds in comparison to the parent tetraphenylporphyrin (TPP).

Fusion of porphyrins with PAH substituents through the formation of an additional bond between the substituent and the $\beta$-pyrrolic position of the porphyrin core could be another advanced strategy. ${ }^{6}$ A wide variety of $\pi$-extended porphyrins fused at meso- and $\beta$-positions of porphyrins with azulene, benzene, naphthalene, and pyrene have been reported. ${ }^{7}$ Anderson and co-workers reported anthracene and bis-anthracene fused porphyrin monomer and dimer with near-infrared (NIR) absorption at $973 \mathrm{~nm}$ and $1495 \mathrm{~nm}$, respectively. ${ }^{8}$ However, in these systems, the optical properties of the molecular superstructure depends solely on the porphyrin moiety. Reports on carbon-rich porphyrins with structural features that are dominated by PAHs are limited. While the phenyl moieties mainly impart solubility, large PAHs are believed to have noticeable impact on the molecular properties of TPP and it paves the way towards novel materials for nanoelectronics. The combination of graphene model systems and porphyrins has been recently achieved with the close-contact chromophores; for example, hexa-perihexabenzocoronene(HBC)-“superbenzene"-porphyrin conjugates by Jux and co-workers. ${ }^{9}$ With the aim of developing such closest contact chromophores, we have designed and synthesized a series of meso-tetraphenylbenzene substituted porphyrins (Figure 1).

\footnotetext{
*For correspondence
}

Electronic supplementary material: The online version of this article (https://doi.org/10.1007/s12039-018-1485-5) contains supplementary material, which is available to authorized users. 



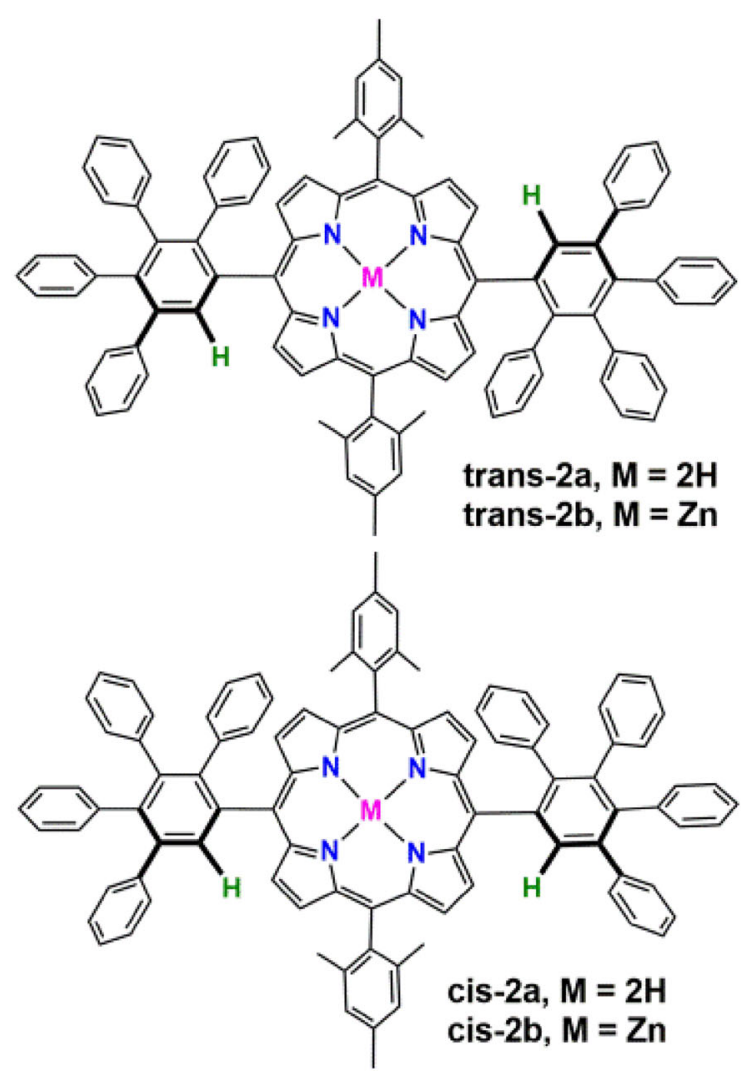

cis-2b, $\mathrm{M}=\mathrm{Zn}$

Figure 1. Chemical structures of polyphenyl substituted porphyrins.

\section{Experimental section}

\subsection{General methods}

All manipulations of the complexes were carried out using standard Schlenk techniques under nitrogen atmosphere. All the solvents were freshly distilled using standard procedures. Tetraphenylcyclopentadienone, ethyl propiolate, mesitaldehyde, DDQ, triethylamine, zinc acetate were procured from Aldrich and were used as such. Pyrrole was distilled before use. Fluorescence quantum yields were measured by using the reference compounds TPP and ZnTPP in toluene.

\subsection{Instrumentation}

All 1D and 2D NMR spectra (COSY and NOESY) were recorded on Bruker 400 and $500 \mathrm{MHz}$ instruments. HRMSElectro Spray Ionization (ESI) mass spectra were recorded on Bruker micro TOF-Q II. Matrix Assisted Laser Desorption/Ionization (MALDI) was recorded on a Bruker ultraflex TOF/TOF mass Spectrometer. UV-Visible absorption studies were performed on an Agilent Cary-100 and fluorescence emission spectra were recorded on a Horiba Fluorolog spectrophotometer with $1 \mathrm{~cm}$, same pair of cuvettes. Lifetime measurements were obtained using a time-correlated single photon counting (TCSPC) spectrometer (Delta Flex-01DD/HORIBA), using a pulsed diode laser (NanoLED, N-375) source at $408 \mathrm{~nm}$. Picosecond photon detection module with photomultiplier tube was used as detector. Instrument response function was recorded by using aqueous solution of Ludox. All TCSPC measurements gave 10000 counts in the peak channel, and IBH DAS6 (version) software was used for fitting the decays. All spectra were taken at 298 K. Cyclic and Differential Pulse voltammograms were carried out using a three-electrode system consisting of a Pt disk working electrode, $\mathrm{Ag} / \mathrm{Ag}^{+}$reference electrode and Pt-wire counter electrode. Tetrabutyl ammonium hexafluorophosphate $\left(\mathrm{TBAPF}_{6}\right)$ was the supporting electrolyte (0.1 M).

\section{$2.3 X$ X-ray crystallography}

Single-crystal X-ray diffraction data was collected on a Bruker APEX II diffractometer equipped with a graphite monochromator and Mo-K $\alpha(\lambda=0.71073 \AA)$ radiation. Data collection was performed using $\phi$ and $\omega$ scans. All crystal structures were solved by direct methods. The structures were solved using direct methods followed by full matrix least square refinements against $\mathrm{F}_{2}$ (all data HKLF 4 format) using SHELXTL. All calculations were carried out using SHELXL-2014, PLATON 99, and WinGXsystemVer-1.6414 software. Disordered solvent molecules were taken out using the SQUEEZE command in PLATON. All hydrogen atoms were included in idealized positions, and a riding model was used. Non-hydrogen atoms were refined with anisotropic displacement parameters. 


\subsection{Computational details}

Computational calculations were performed with the Gaussian O9 program on KANAD- HPC (IISER-B). The calculations were performed by density functional theory (DFT) method with restricted B3LYP (Becke's three-parameter hybrid exchange functional and Lee-Yang-Parr correlation function) level, employing basis sets 6-31G (d) for H, C, N and LANL2DZ for $\mathrm{Zn}$ in gas phase. To simulate the ground-state absorption spectra, the time-dependent DFT (TD-DFT) calculations were further carried out at the same level of theory to determine first 20 vertical excitations to the excited state of the molecule. All the optimized structures and molecular orbitals (see in Supporting Information) were visualized by the software Jmol viewer.

\subsection{Synthesis and characterization of compounds}

2.5a Ethyl-5',6'-diphenyl-[1,1':2', $1^{\prime \prime}$-terphenyl]-3'-carboxylate $(\mathbf{1 b})$ : A mixture of 2,3,4,5-tetraphenylcyclopenta2,4-dien-1-one (1a, $0.5 \mathrm{~g}, 1.30 \mathrm{mmol})$ and ethyl propiolate $(0.191 \mathrm{~g}, 1.95 \mathrm{mmol})$ was refluxed in toluene $(2 \mathrm{~mL})$ for $3 \mathrm{~h}$. After cooling to room temperature, the crude reaction mixture was filtered through a plug of silica, washed with $\mathrm{CH}_{2} \mathrm{Cl}_{2}$, followed by removal of the solvent in vacuo and purified by column chromatography (3\% ethyl acetate/hexane) gave 1b (0.54 g, 87\%). ${ }^{1} \mathrm{H}$ NMR (400 $\left.\mathrm{MHz}, \mathrm{CDCl}_{3}\right) \delta 7.88(\mathrm{~s}, 1 \mathrm{H}), 7.22-7.07(\mathrm{~m}, 8 \mathrm{H}), 7.04$ $(\mathrm{m}, 2 \mathrm{H}), 6.98-6.83(\mathrm{~m}, 6 \mathrm{H}), 6.77(\mathrm{~m}, 4 \mathrm{H}), 4.03(\mathrm{q}, J=$ $7.1 \mathrm{~Hz}, 2 \mathrm{H}), 0.93(\mathrm{t}, J=7.1 \mathrm{~Hz}, 3 \mathrm{H}) .{ }^{13} \mathrm{C}$ NMR $(126 \mathrm{MHz}$, $\left.\mathrm{CDCl}_{3}\right) \delta 168.82,142.96,142.24,140.98,140.95,140.08$, $139.97,139.32,139.23,132.06,131.27,131.12,129.85$, $127.66,127.14,126.99,126.72,126.55,126.33,125.95$, 125.66, 61.00, 13.66. HR-MS (ESI): $\mathrm{m} / z=477.1835$ (found, $\left.[\mathrm{M}+\mathrm{Na}]^{+}\right) ; 477.1830$ (calcd. for $\mathrm{C}_{33} \mathrm{H}_{26} \mathrm{O}_{2} \mathrm{Na}$ ).

$2.5 \mathrm{~b} \quad\left(3^{\prime}, 6^{\prime}\right.$-diphenyl-[1,1',2', $1^{\prime \prime}$-terphenyl $\left.]-4^{\prime}-y l\right)$ methanol (1c): To a solution of $\mathbf{1 b}(0.642 \mathrm{~g}, 1.41 \mathrm{mmol})$ in THF $(40 \mathrm{~mL})$ was added $\mathrm{LiAlH}_{4}(0.234 \mathrm{~g}, 6.18 \mathrm{mmol})$ and the resulting mixture was stirred at room temperature for $15 \mathrm{~h}$. The reaction was quenched with $\mathrm{H}_{2} \mathrm{O}(100 \mathrm{~mL})$ and extracted with $\mathrm{CH}_{2} \mathrm{Cl}_{2}(2 \times 100 \mathrm{~mL})$. The combined organic layers were dried $\left(\mathrm{Na}_{2} \mathrm{SO}_{4}\right)$, filtered and evaporated to give $\mathbf{1 c}$ as a white solid $(0.57 \mathrm{~g}, 98 \%) .{ }^{1} \mathrm{H}$ NMR $\left(400 \mathrm{MHz}, \mathrm{CDCl}_{3}\right) \quad \delta 7.66$ (s, 1H), 7.22-7.05 (m, 10H), 6.95-6.71 (m, 10H), $4.56(\mathrm{~s}$, 2H). ${ }^{13} \mathrm{C} \mathrm{NMR}\left(126 \mathrm{MHz}, \mathrm{CDCl}_{3}\right) \delta 206.89,141.75,141.10$, $139.89,139.81,139.69,139.54,139.09,137.91,131.46$, $131.19,130.13,129.90,128.91,127.68,127.59,126.90$, 126.61, 126.56, 126.26, 125.61, 125.39, 63.75, 30.93, 21.04. HR-MS (ESI): $m / z=435.1757$ (found, $[\mathrm{M}+\mathrm{Na}]^{+}$); 435.1719 (calcd. for $\mathrm{C}_{31} \mathrm{H}_{24} \mathrm{ONa}$ ).

2.5c Tetraphenylbenzaldehyde $(\boldsymbol{I d})$ : To a solution of 1c $(0.412 \mathrm{~g}, 1 \mathrm{mmol})$ in $\mathrm{CH}_{2} \mathrm{Cl}_{2}(15 \mathrm{~mL})$ containing $4 \AA$ molecular sieves was added $N$-methylmorpholine- $N$-oxide (NMO, $0.203 \mathrm{~g}, 1.74 \mathrm{mmol}$ ) followed by tetrapropylammonium perruthenate (TPAP, $0.018 \mathrm{~g}, 0.05 \mathrm{mmol}$ ). The reaction mixture darkened quickly and was stirred for $1 \mathrm{~h}$ at room temperature before washing with sodium sulphite solution $(10 \mathrm{~mL})$, brine $(10 \mathrm{~mL})$ and saturated $\mathrm{CuSO}_{4}$ solution $(10 \mathrm{~mL})$. The solution was dried $\left(\mathrm{Na}_{2} \mathrm{SO}_{4}\right)$, filtered, evaporated and redissolved with the minimum volume of $\mathrm{CH}_{2} \mathrm{Cl}_{2}$. A dark solid precipitate was separated and filtrate was evaporated to give 1d as a white solid $(0.38 \mathrm{~g}, 93 \%) .{ }^{1} \mathrm{H}$ NMR $\left(400 \mathrm{MHz}, \mathrm{CDCl}_{3}\right) \quad \delta 9.82(\mathrm{~s}, 1 \mathrm{H}), 8.14(\mathrm{~s}, 1 \mathrm{H}), 7.22-7.16$ $(\mathrm{m}, 6 \mathrm{H}), 7.15-7.09(\mathrm{~m}, 4 \mathrm{H}), 6.93(\mathrm{~m}, 3 \mathrm{H}), 6.91-6.86(\mathrm{~m}$, $3 \mathrm{H}), 6.81(\mathrm{~m}, 2 \mathrm{H}), 6.77(\mathrm{~m}, 2 \mathrm{H}) .{ }^{13} \mathrm{C}$ NMR $(126 \mathrm{MHz}$, $\left.\mathrm{CDCl}_{3}\right) \quad \delta 192.58,145.62,144.29,142.56,141.63,140.74$, $139.14,138.67,136.39,133.46,131.18,131.07,130.94$, $129.81,127.92,127.74,127.55,127.23,127.10,126.91$, 126.69, 126.21, 125.89. HR-MS (ESI): $\mathrm{m} / z=411.1765$ (found, $[\mathrm{M}+\mathrm{H}]^{+}$); 411.1749 (calcd. for $\mathrm{C}_{31} \mathrm{H}_{23} \mathrm{O}$ ).

\section{5d 5,15-bis(tetraphenylbenzene)-10,20-bis(2,4,6-tri-} methylphenyl)-21,23H-porphine (trans-2a and cis-2a): Tetraphenylbenzaldehyde (1d, $0.052 \mathrm{~g}, 0.128 \mathrm{mmol})$ and mesityl dipyrromethane $(0.034 \mathrm{~g}, 0.128 \mathrm{mmol})$ were placed in a dry flask under $\mathrm{N}_{2}$ and dissolved in $\mathrm{CH}_{2} \mathrm{Cl}_{2}(30 \mathrm{~mL})$. The solution was degassed for $20 \mathrm{~min}$ by repeated evacuation and purging with nitrogen. Trifluoroacetic acid (0.984 $\mu \mathrm{L}, 0.013 \mathrm{mmol}$ ) was added and the reaction mixture was stirred for $8 \mathrm{~h}$ in dark at room temperature. DDQ (0.038 g, $0.167 \mathrm{mmol}$ ) was then added and stirring continued for $15 \mathrm{~min}$. After quenching the reaction mixture by the addition of triethylamine $(2 \mathrm{~mL})$, the mixture was passed over a short plug of silica $\left(\mathrm{CH}_{2} \mathrm{Cl}_{2}\right)$. After evaporation, the residue was purified by column chromatography over silica to give a purple solid $(0.01 \mathrm{~g}, 3 \%)$ (trans-2a) and $(0.018$ g, 5\%) (cis-2a). Compound trans-2a: ${ }^{1} \mathrm{H}$ NMR $(400 \mathrm{MHz}$, $\left.\mathrm{CDCl}_{3}\right) \delta 8.95(\mathrm{~d}, J=4.6 \mathrm{~Hz}, 2 \mathrm{H}), 8.52(\mathrm{~d}, J=4.5 \mathrm{~Hz}$, 2H), $8.29(\mathrm{~s}, 1 \mathrm{H}), 7.28(\mathrm{~d}, J=6.7 \mathrm{~Hz}, 2 \mathrm{H}), 7.11(\mathrm{t}, J=$ $7.3 \mathrm{~Hz}, 6 \mathrm{H}), 7.09-6.97(\mathrm{~m}, 6 \mathrm{H}), 6.88(\mathrm{~m}, 4 \mathrm{H}), 6.73(\mathrm{~d}, J$ $=7.4 \mathrm{~Hz}, 2 \mathrm{H}), 5.97(\mathrm{~m}, 3 \mathrm{H}), 2.62(\mathrm{~s}, 3 \mathrm{H}), 1.74(\mathrm{~s}, 6 \mathrm{H})$, $-2.88(\mathrm{~s}, 1 \mathrm{H}) .{ }^{13} \mathrm{C}$ NMR $\left(101 \mathrm{MHz}, \mathrm{CDCl}_{3}\right) \quad \delta 150.33$, $143.92,141.73,140.74,140.41,140.23,139.91,139.44$, $138.47,137.57,135.66,131.90,131.83,131.76,130.95$, $130.27,127.67,127.08,126.67,126.23,125.84,125.39$, $124.57,118.29,117.78,29.72,21.51,1.03$. HR-MS (ESI): $\mathrm{m} / \mathrm{z}=1307.6057$ (found, $[\mathrm{M}+\mathrm{H}]^{+}$); 1307.5986 (calcd. for $\mathrm{C}_{98} \mathrm{H}_{75} \mathrm{~N}_{4}$ ). UV-Vis (dichloromethane) $\lambda_{\max }, \mathrm{nm}(\varepsilon): 424 \mathrm{~nm}$ $\left(9.62 \times 10^{5} \mathrm{M}^{-1} \mathrm{~cm}^{-1}\right), 520 \mathrm{~nm}\left(0.53 \times 10^{5} \mathrm{M}^{-1} \mathrm{~cm}^{-1}\right)$. Compound cis-2a: ${ }^{1} \mathrm{H}$ NMR $\left(400 \mathrm{MHz}, \mathrm{CDCl}_{3}\right) \quad \delta 8.96(\mathrm{~d}, J=$ $4.6 \mathrm{~Hz}, 2 \mathrm{H}), 8.53(\mathrm{~d}, J=4.6 \mathrm{~Hz}, 2 \mathrm{H}), 8.10(\mathrm{~s}, 1 \mathrm{H}), 7.26(\mathrm{~s}$, 2H), $7.07(\mathrm{~m}, 12 \mathrm{H}), 6.98-6.84(\mathrm{~m}, 6 \mathrm{H}), 6.22(\mathrm{t}, J=7.4$ $\mathrm{Hz}, 2 \mathrm{H}), 6.14(\mathrm{t}, J=7.2 \mathrm{~Hz}, 1 \mathrm{H}), 2.62(\mathrm{~s}, 3 \mathrm{H}), 1.84(\mathrm{~s}, 3 \mathrm{H})$, 1.67 (s, 3H), -2.82 (s, 1H). ${ }^{13} \mathrm{C}$ NMR (101 MHz, CDCl3) $\delta 143.32,141.68,140.92,140.47,140.27,140.16,140.00$, $139.66,139.30,138.54,138.39,137.54,136.24,131.88$, $131.78,131.18,130.26,127.69,127.60,127.07,126.68$, $126.17,125.77,125.36,124.88,118.27,118.23,117.75$, $29.72,21.74,21.67,21.62,21.49,1.04$. HR-MS (ESI): $\mathrm{m} / \mathrm{z}=1307.6057$ (found, $[\mathrm{M}+\mathrm{H}]^{+}$); 1307.5986 (calcd. for $\mathrm{C}_{98} \mathrm{H}_{75} \mathrm{~N}_{4}$ ). UV-Vis (dichloromethane) $\lambda_{\max }, \mathrm{nm}(\varepsilon): 424 \mathrm{~nm}$ $\left(10.16 \times 10^{5} \mathrm{M}^{-1} \mathrm{~cm}^{-1}\right), 520 \mathrm{~nm}\left(0.41 \times 10^{5} \mathrm{M}^{-1} \mathrm{~cm}^{-1}\right)$. 
2.5e 5,15-bis(tetraphenylbenzene)-10,20-bis(2,4,6-trimethylphenyl)porphyrinato $\mathrm{Zn}(\mathrm{II})$ (trans-2b): To a chloroform $(5 \mathrm{~mL})$ solution of compound trans-2a $(0.05 \mathrm{~g}$, $0.04 \mathrm{mmol})$ was added zinc acetate dihydrate $(0.252 \mathrm{~g}, 1.15$ $\mathrm{mmol})$ in methanol $(5 \mathrm{~mL})$. The reaction mixture was stirred for $1 \mathrm{~h}$ at room temperature and concentrated by rotary evaporation. The crude mixture was passed through a short pad of silica gel, eluting with dichloromethane/petroleum ether (1:9). All fractions containing trans-2b were rotaryevaporated to give a bright red solid $(0.047 \mathrm{~g}, 90 \%) .{ }^{1} \mathrm{H}$ NMR $\left(700 \mathrm{MHz}, \mathrm{CDCl}_{3}\right) \delta 9.04(\mathrm{~d}, J=4.4 \mathrm{~Hz}, 2 \mathrm{H})$, $8.61(\mathrm{~d}, J=4.3 \mathrm{~Hz}, 2 \mathrm{H}), 8.39(\mathrm{~s}, 1 \mathrm{H}), 7.34(\mathrm{~d}, J=8.0$ $\mathrm{Hz}, 2 \mathrm{H}), 7.09(\mathrm{~m}, 11 \mathrm{H}), 6.88(\mathrm{~d}, J=7.6 \mathrm{~Hz}, 4 \mathrm{H}), 6.66(\mathrm{~d}$, $\mathrm{J}=7.9 \mathrm{~Hz}, 2 \mathrm{H}), 5.90(\mathrm{t}, J=7.5 \mathrm{~Hz}, 2 \mathrm{H}), 5.84(\mathrm{~s}, 1 \mathrm{H})$, $2.63(\mathrm{~s}, 3 \mathrm{H}), 1.74(\mathrm{~s}, 6 \mathrm{H}) \cdot{ }^{13} \mathrm{C} \mathrm{NMR}\left(176 \mathrm{MHz}, \mathrm{CDCl}_{3}\right) \delta$ $150.29,150.23,150.19,149.42,144.04,141.88,141.21$, $140.47,140.44,140.31,140.16,139.79,139.26,139.14$, $138.30,137.28,135.01,132.42,131.95,131.75,130.77$, $130.33,130.14,127.65,127.57,127.08,126.64,126.20$, $125.75,125.43,125.34,124.31,119.00,118.62,41.36,36.10$, $36.09,34.68,34.54,31.61,29.07,22.67,22.64,21.50$, $21.45,18.78,14.34,14.14,11.45$. MS (MALDI-TOF, without matrix) $\mathrm{m} / z$ calcd. for $\mathrm{C}_{98} \mathrm{H}_{72} \mathrm{~N}_{4} \mathrm{Zn}$ : 1368.5048 , found: 1368.547. UV-Vis (dichloromethane) $\lambda_{\max }, \mathrm{nm}(\varepsilon): 425 \mathrm{~nm}$ $\left(6.04 \times 10^{5} \mathrm{M}^{-1} \mathrm{~cm}^{-1}\right), 554 \mathrm{~nm}\left(0.29 \times 10^{5} \mathrm{M}^{-1} \mathrm{~cm}^{-1}\right)$.

$2.5 f$ 5,15-bis(tetraphenylbenzene)-10,20-bis(2,4,6-trimethylphenyl)porphyrinato Zinc(II) (cis-2b): To a chloroform $(5 \mathrm{~mL})$ solution of compound cis-2a $(0.05 \mathrm{~g}$, $0.04 \mathrm{mmol})$ was added zinc acetate dihydrate $(0.252 \mathrm{~g}, 1.15$ $\mathrm{mmol})$ in methanol $(5 \mathrm{~mL})$. The reaction mixture was stirred for $1 \mathrm{~h}$ at room temperature and concentrated by rotary evaporation. The crude mixture was passed through a short pad of silica gel and eluted with dichloromethane/petroleum ether (1:9). All fractions containing cis-2b were rotary-evaporated to give a bright red solid $(0.049 \mathrm{~g}, 94 \%) .{ }^{1} \mathrm{H}$ NMR $(700 \mathrm{MHz}$, $\left.\mathrm{CDCl}_{3}\right) \quad \delta 8.97(\mathrm{~d}, J=4.4 \mathrm{~Hz}, 2 \mathrm{H}), 8.54(\mathrm{~d}, J=4.4 \mathrm{~Hz}$, $2 \mathrm{H}), 8.23(\mathrm{~s}, 1 \mathrm{H}), 7.23(\mathrm{~s}, 1 \mathrm{H}), 7.18(\mathrm{~d}, J=5.1 \mathrm{~Hz}, 3 \mathrm{H})$, $7.08(\mathrm{~d}, J=7.3 \mathrm{~Hz}, 2 \mathrm{H}), 7.05(\mathrm{t}, J=7.5 \mathrm{~Hz}, 2 \mathrm{H}), 6.98$ $(\mathrm{m}, 6 \mathrm{H}), 6.84-6.76(\mathrm{~m}, 5 \mathrm{H}), 6.03(\mathrm{~s}, 2 \mathrm{H}), 5.95(\mathrm{~s}, 1 \mathrm{H}), 2.56$ (s, 3H), $1.72(\mathrm{~s}, 3 \mathrm{H}), 1.62$ (s, 3H). ${ }^{13} \mathrm{C}$ NMR $(176 \mathrm{MHz}$, $\left.\mathrm{CDCl}_{3}\right) \quad \delta 171.19,150.18,149.41,143.54,141.83,141.12$, $140.59,140.50,140.32,139.72,139.43,139.21,139.16$, $138.26,137.25,135.57,132.37,131.94,131.76,131.06$, $130.34,130.15,127.59,127.53,127.07,126.64,126.18$, $125.74,125.71,125.32,124.48,118.92,118.62,60.42,35.08$, 34.69, 31.62, 29.08, 25.30, 22.68, 21.67, 21.55, 21.51, 21.06, $20.73,18.79,14.21,14.15,11.46$. MS (MALDI-TOF, without matrix) $\mathrm{m} / \mathrm{z}$ calcd. for $\mathrm{C}_{98} \mathrm{H}_{72} \mathrm{~N}_{4} \mathrm{Zn}$ : 1368.5048 , found: 1368.547. UV-Vis (dichloromethane) $\lambda_{\max }, \mathrm{nm}(\varepsilon): 425 \mathrm{~nm}$ $\left(4.87 \times 10^{5} \mathrm{M}^{-1} \mathrm{~cm}^{-1}\right), 554 \mathrm{~nm}\left(0.122 \times 10^{5} \mathrm{M}^{-1} \mathrm{~cm}^{-1}\right)$.

$2.5 \mathrm{~g}$ 10,20-bis(tetraphenylbenzene)-21,23H-porphine (cis-3a): Compound $1 \mathrm{~d}(0.2 \mathrm{~g}, 0.49 \mathrm{mmol})$ and meso free dipyrromethane $(0.071 \mathrm{~g}, 0.49 \mathrm{mmol})$ were placed in a dry round bottomed flask under $\mathrm{N}_{2}$ and dissolved in $\mathrm{CH}_{2} \mathrm{Cl}_{2}$ $(80 \mathrm{~mL})$. The solution was degassed for $20 \mathrm{~min}$, by repeated evacuation and purging with nitrogen. Trifluoroacetic acid (3.7 $\mu \mathrm{L}, 0.049 \mathrm{mmol}$ ) was added and the reaction mixture was stirred for $8 \mathrm{~h}$ in dark at room temperature. DDQ $(0.144$ $\mathrm{g}, 0.633 \mathrm{mmol}$ ) was added and stirring continued for $15 \mathrm{~min}$. After quenching the reaction mixture by the addition of triethylamine $(3 \mathrm{~mL})$, the mixture was passed over a short plug of silica $\left(\mathrm{CH}_{2} \mathrm{Cl}_{2}\right)$. After evaporation, the residue was purified by column chromatography over silica to give a desired compound cis-3a $(0.135 \mathrm{~g}, 13 \%) .{ }^{1} \mathrm{H}$ NMR $\left(400 \mathrm{MHz}, \mathrm{CDCl}_{3}\right) \quad \delta$ 10.09 (s, 1H), $9.24(\mathrm{~s}, 4 \mathrm{H}), 8.18(\mathrm{~s}, 1 \mathrm{H}), 7.28(\mathrm{~d}, J=6.8 \mathrm{~Hz}$, 2H), 7.18-7.02 (m, 10H), 6.98-6.86 (m, 5H), $6.16(\mathrm{t}, J=$ 7.6 Hz, 2H), 6.10-6.02 (m, 1H), -3.35 (s, 1H). ${ }^{13} \mathrm{C}$ NMR $\left(101 \mathrm{MHz}, \mathrm{CDCl}_{3}\right) \delta 143.35,141.64,141.02,140.45$, $140.24,140.17,140.08,140.02,139.73,138.61,136.37$, $131.88,131.80,131.22,131.15,130.26,127.63,127.13$, $126.73,126.26,126.16,125.82,125.78,125.43,124.89$. HRMS (ESI): $m / z=1071.4448$ (found, $[\mathrm{M}+\mathrm{H}]^{+}$); 1071.4421 (calcd. for $\mathrm{C}_{80} \mathrm{H}_{55} \mathrm{~N}_{4}$ ). UV-Vis (dichloromethane) $\lambda_{\max }$, $\mathrm{nm}(\varepsilon)$ : $412 \mathrm{~nm}\left(10.46 \times 10^{5} \mathrm{M}^{-1} \mathrm{~cm}^{-1}\right), 507 \mathrm{~nm}(0.84 \times$ $\left.10^{5} \mathrm{M}^{-1} \mathrm{~cm}^{-1}\right)$.

$2.5 \mathrm{~h} \quad$ 10,20-bis (tetraphenylbenzene)porphyrinato $\mathrm{Zn}$ (II) (cis-3b): Compound cis-3a (0.1 g, $0.0933 \mathrm{mmol})$ was dissolved in $8 \mathrm{~mL}$ chloroform. To this solution $8 \mathrm{~mL}$ methanolic solution of zinc acetate dihydrate $(0.615 \mathrm{~g}, 2.80$ mmol) was added. The reaction mixture was stirred for $1 \mathrm{~h}$ at room temperature. After concentrating the reaction mixture by rotary evaporation, the crude mixture was eluted with petroleum ether/dichloromethane through a short pad of silica gel. All fractions containing compound cis-3b were rotaryevaporated to give a bright red solid $(0.093 \mathrm{~g}, 88 \%) .{ }^{1} \mathrm{H}$ NMR $\left(700 \mathrm{MHz}, \mathrm{CDCl}_{3}\right) \quad \delta 10.04(\mathrm{~s}, 1 \mathrm{H}), 9.26(\mathrm{~d}, J=9.2 \mathrm{~Hz}, 4 \mathrm{H})$, $8.29(\mathrm{~s}, 1 \mathrm{H}), 7.23-6.93(\mathrm{~m}, 11 \mathrm{H}), 6.78(\mathrm{~m}, 6 \mathrm{H}), 6.00-5.71$ $(\mathrm{m}, 3 \mathrm{H}) .{ }^{13} \mathrm{C}$ NMR $\left(176 \mathrm{MHz}, \mathrm{CDCl}_{3}\right) \quad \delta 150.31,149.16$, $143.54,141.80,141.03,140.64,140.50,140.34,139.88$, $138.42,135.68,132.71,132.62,131.96,131.81,131.39$, $131.01,130.82,130.35,127.68,127.64,127.15,126.71$, $126.24,125.81,125.73,125.63,125.39,124.46,118.69$, $105.87,31.62,29.73,22.69,14.16$. MS (MALDI-TOF, without matrix) $\mathrm{m} / \mathrm{z}$ calcd. for $\mathrm{C}_{80} \mathrm{H}_{52} \mathrm{~N}_{4} \mathrm{Zn}$ : 1132.3483 , found: 1132.442. UV-Vis (dichloromethane) $\lambda_{\max }, \mathrm{nm}(\varepsilon): 414 \mathrm{~nm}$ $\left(4.89 \times 10^{5} \mathrm{M}^{-1} \mathrm{~cm}^{-1}\right), 541 \mathrm{~nm}\left(0.154 \times 10^{5} \mathrm{M}^{-1} \mathrm{~cm}^{-1}\right)$.

\section{Results and Discussion}

\subsection{Synthesis and characterization}

The PAH-appended porphyrins reported earlier have been mostly synthesized by Suzuki-Miyaura cross coupling reaction of meso-brominated porphyrin with boronic acid of PAH which requires postfunctionalization of the porphyrin moiety. ${ }^{10}$ In the present work, our synthetic strategy involves MacDonald [2+2] cross condensation reaction of dipyrromethane with a carboxaldehyde. ${ }^{11}$ This approach provides the 
<smiles>O=C1C(c2ccccc2)=C(c2ccccc2)C(c2ccccc2)=C1c1ccccc1</smiles>

$1 \mathrm{a}$<smiles>CCOC(=O)c1cc(-c2ccccc2)c(-c2ccccc2)c(-c2ccccc2)c1-c1ccccc1</smiles>

$1 b$<smiles>OCc1cc(-c2ccccc2)c([18OH])c(-c2ccccc2)c1-c1ccccc1</smiles>

1c<smiles>O=Cc1cc(-c2ccccc2)c(-c2ccccc2)c(-c2ccccc2)c1-c1ccccc1</smiles>

1d

Scheme 1. Synthesis of $\mathbf{1 b}, \mathbf{1 c}$ and 1d. (a) ethyl propiolate, toluene, reflux, 3 h, 87\%; (b) $\mathrm{LiAlH}_{4}, \mathrm{THF}$ 15 h, rt, 98\%; (c) NMO, TPAP, $\mathrm{CH}_{2} \mathrm{Cl}_{2}, 1$ h, rt, $93 \%$.

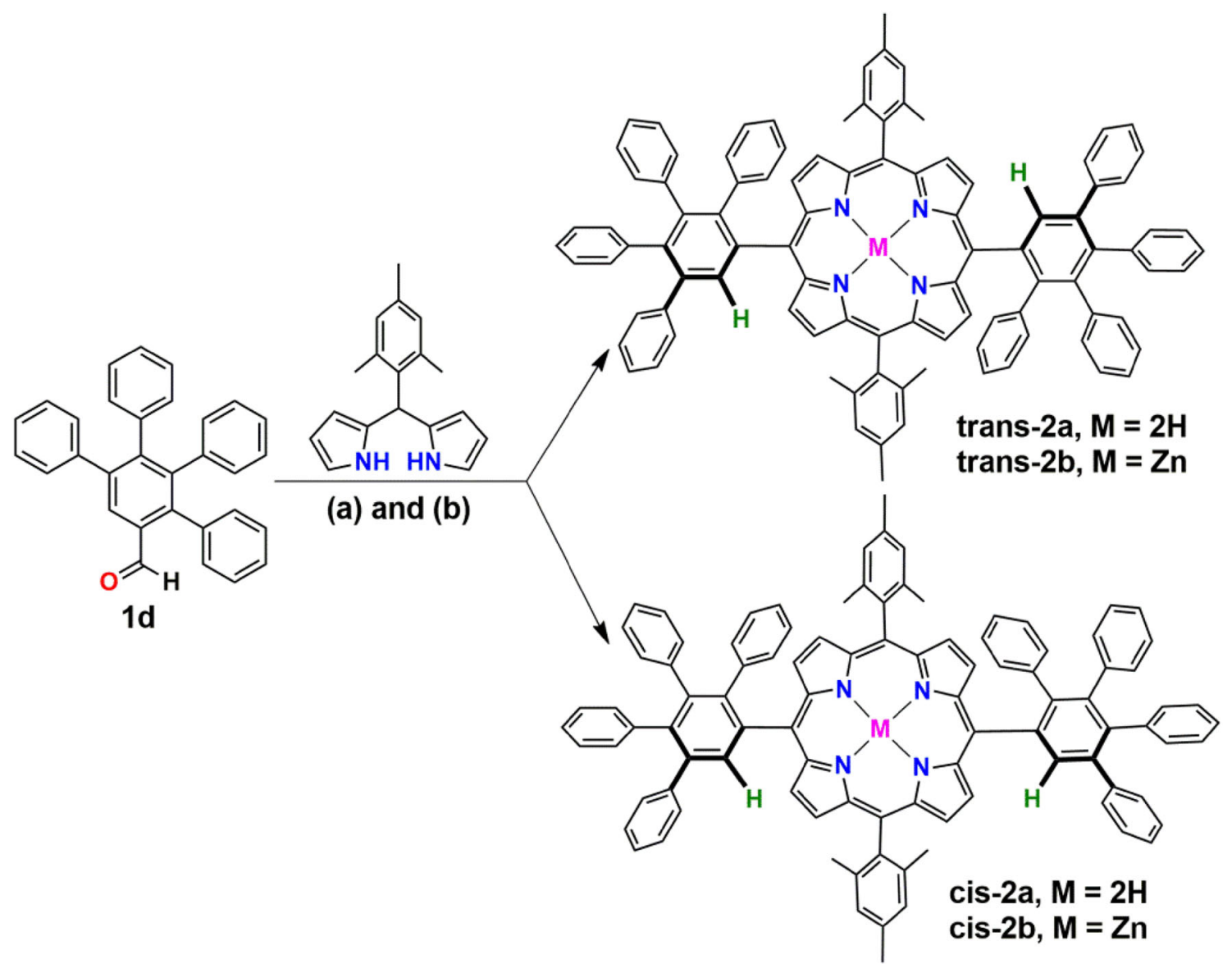

Scheme 2. Synthesis of trans-2a/2b, and cis-2a/2b. (a) $\mathrm{CF}_{3} \mathrm{COOH}, 8 \mathrm{~h}, \mathrm{DDQ}, 3 \%$ (trans-2a) and $5 \%$

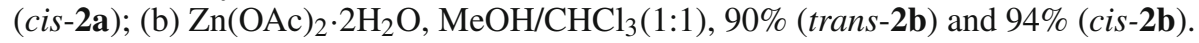

scope for realizing more examples for introducing highly conjugated porphyrins with a variety of polyphenyl or polyaromatic substituents by one-pot synthesis. For the synthesis of precursor 1d, tetraphenylcyclopentadienone (1a) was refluxed with an excess of ethyl propionate in toluene to give compound $\mathbf{1 b}$ in quantitative yield. Reduction of the tetraphenylbenzene ester (1c) by $\mathrm{LiAlH}_{4}$ and subsequent oxidation in presence of stiochiometric $\mathrm{N}$-methylmorpholine$N$-oxide (NMO)/catalytic tetrapropylammonium perruthenate (TPAP) gave 1d in $93 \%$ of yield ${ }^{12}$ (Scheme $1)$.
An acid-catalyzed condensation of an equimolar mixture of 5-(2,4,6-trimethylphenyl)dipyrromethane with tetraphenylbenzenecarboxaldehyde (1d) in the presence of trifluoroacetic acid gave compound 5,15-bis(tetraphenylbenzene)-10,20-bis(2,4,6-trimethylphenyl)-21,23Hporphine trans-2a and cis-2a in 3\% and 5\% yield, respectively (Scheme 2). Thin layer chromatography (TLC) of the reaction mixture showed two spots which were separated by column chromatography. Both the compounds exhibited identical isotopic pattern in high resolution-electron spray ionization-mass spectrometry (HR-ESI-MS) with molecular ion peak at $\mathrm{m} / \mathrm{z}=$ 

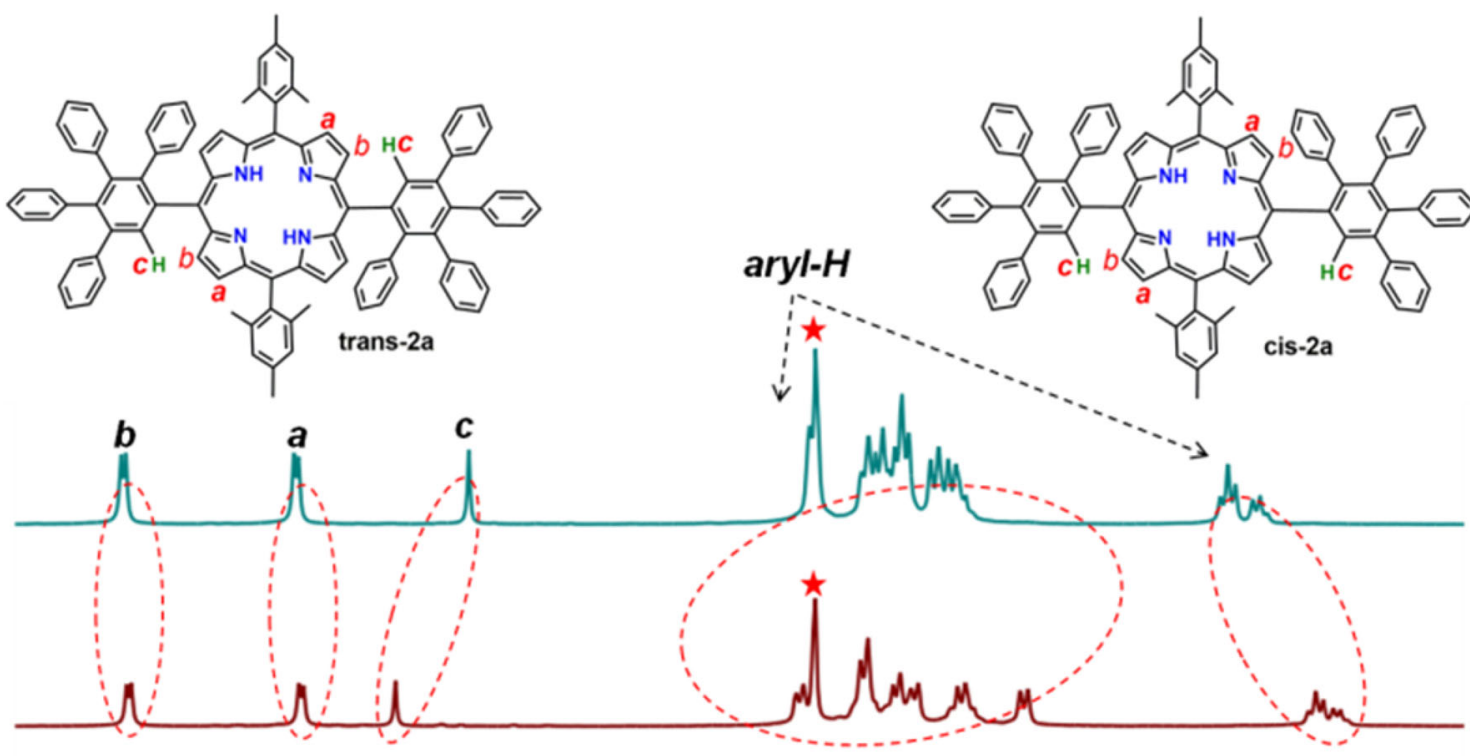

8.2

(ppm)

6.8

Figure 2. $\quad 400 \mathrm{MHz}^{1} \mathrm{H} \mathrm{NMR}$ spectra of trans-2a (bottom) and cis-2a (top) in $\mathrm{CDCl}_{3}$ at $25^{\circ} \mathrm{C}$. The asterisks (*) denote residual solvent peaks.

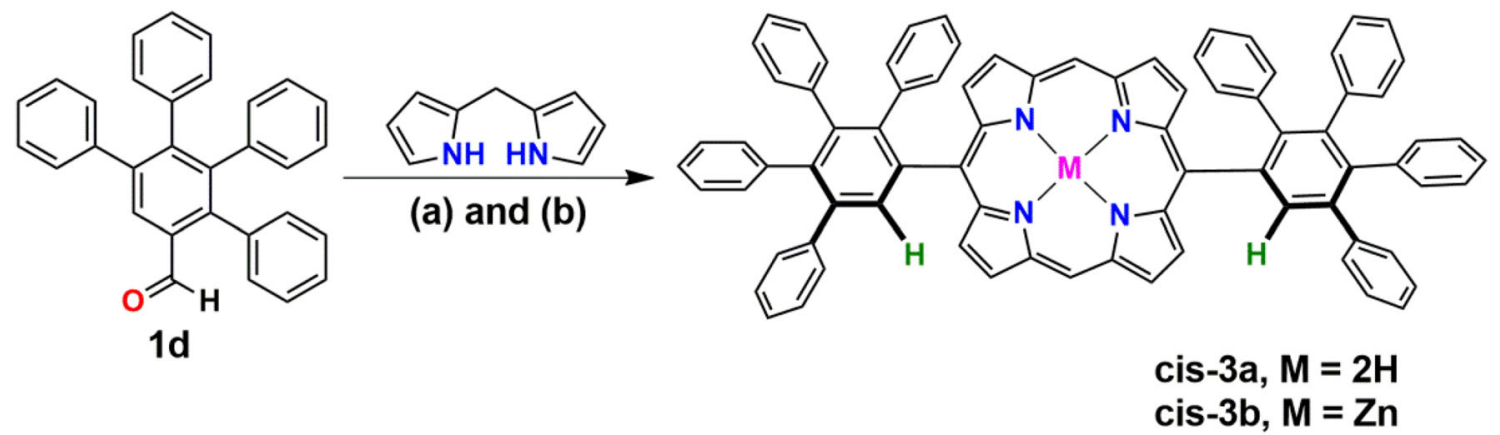

Scheme 3. Synthesis of cis-3a and cis-3b. (a) $\mathrm{CH}_{3} \mathrm{COOH}, 8 \mathrm{~h}$, DDQ, $13 \%$; (b) $\mathrm{Zn}(\mathrm{OAc})_{2} \cdot 2 \mathrm{H}_{2} \mathrm{O}$, $\mathrm{MeOH} / \mathrm{CHCl}_{3}(1: 1), 88 \%$.

1307.5986 (calcd. for $\mathrm{C}_{98} \mathrm{H}_{74} \mathrm{~N}_{4}[\mathrm{M}]^{+}=1307.6057$ ) (see in Supporting Information).

Both the compounds had identical UV-Visible absorption spectrum and only a subtle difference was observed in ${ }^{1} \mathrm{H}$ NMR spectrum (Figure 2, Figures S10-S13 in Supporting Information). Single crystal X-ray diffraction studies confirmed the molecules to be atropisomers (vide infra). The eight $\beta$-pyrrolic protons of trans-2a resonate as two doublets at $\delta 8.52$ and $\delta 8.29 \mathrm{ppm}$ with a typical coupling constant of ${ }^{3} J_{\mathrm{H}-\mathrm{H}} \sim 4.5 \mathrm{~Hz}$. The unsubstituted meso-phenylic protons resonate as a singlet at $\delta 8.29 \mathrm{ppm}$. The remaining phenylic protons resonate in a range of $\delta 5.97$ to $7.28 \mathrm{ppm}$. The ${ }^{1} \mathrm{H}$ NMR spectra of cis-2a was similar to that of trans-2a, except slight upfield shift for unsubstituted meso-phenylic proton (Figure 2). Zinc metallation for trans-2a and cis-2a have been carried out with $\mathrm{Zn}(\mathrm{OAc})_{2} \cdot 2 \mathrm{H}_{2} \mathrm{O}$ in chloroform/methanol $(1: 2, v / v)$ (Scheme 2). Matrixassisted laser desorption/ionization-time of flight (MALDI-TOF) mass spectrometry showed molecular ion peak at $m / z=1368.547$ (calcd. for $\mathrm{C}_{98} \mathrm{H}_{72} \mathrm{~N}_{4} \mathrm{Zn}$ $[\mathrm{M}]^{+}=1368.5048$ ) (see in Supporting Information) for both the compounds.

Intriguingly, condensation of 1:1 molar ratio of $\mathbf{1 d}$ with meso-free dipyrromethane in the presence of TFA followed by oxidation with DDQ gave exclusively only one product cis-3a (Scheme 3). Zinc metallated compound $c i s-\mathbf{3 b}$ was achieved by treating cis-3a with $\mathrm{Zn}(\mathrm{OAc})_{2} \cdot 2 \mathrm{H}_{2} \mathrm{O}$ in chloroform/methanol $(1: 2, \mathrm{v} / \mathrm{v})$ (Scheme 2$)$. The compound cis-3a was confirmed by HRMS with a molecular ion peak at $\mathrm{m} / \mathrm{z}=$ 1071.4448 (calcd. for $\mathrm{C}_{80} \mathrm{H}_{55} \mathrm{~N}_{4}[\mathrm{M}]^{+}=1071.4421$ ). 



Figure 3. ${ }^{1} \mathrm{H}$ NMR variable temperature of trans-2a (a) and cis-3a (b). The asterisks $(*)$ denote residual solvent peaks.

The meso-protons of $c i s-\mathbf{3 a}$ resonate as a singlet at $\delta$ $10.09 \mathrm{ppm}$ and eight $\beta$-pyrrolic protons resonate as a doublet at $\delta 9.24 \mathrm{ppm}$, and unsubstituted meso-phenylic protons resonate at $\delta 8.18 \mathrm{ppm}$. The remaining phenylic protons resonate in the range of $\delta 6.2$ to $7.28 \mathrm{ppm}$. The ${ }^{1} \mathrm{H}$ NMR for all compounds was assigned and correlated by ${ }^{1} \mathrm{H}-{ }^{1} \mathrm{H}$ COSY and ${ }^{1} \mathrm{H}-{ }^{1} \mathrm{H}$ ROESY (see Supporting Information).

Indeed, we were surprised to observe the formation of atropisomers in the case of meso-mesityl-substituted porphyrins and the appearance of exclusively only one product in the case of meso-free porphyrin. To understand this counter-intuitive observation, variable temperature ${ }^{1} \mathrm{H}$ NMR investigations for trans-2a and cis-3a were conducted. Variable temperature NMR studies indicated restriction of rotation around $\mathrm{C}_{\text {meso }}-\mathrm{C}_{\mathrm{TPB}}$ bond $\left(\mathrm{C}_{\text {meso }}=\right.$ meso-carbon of porphyrin, $\mathrm{C}_{\mathrm{TPB}}=$ carbon of TPB) (Figure 3). Probably, the splitting of ${ }^{1} \mathrm{H}$ resonance at lowers temperature in trans-2a and cis-3a is due to the unsymmetrical conformation, which can be attributed to restricting of conformational dynamics with decreasing temperature.

\subsection{Single crystal X-ray diffraction studies}

X-ray quality single crystals for solid state structure determination were obtained from slow evaporation 
(a)

(b)
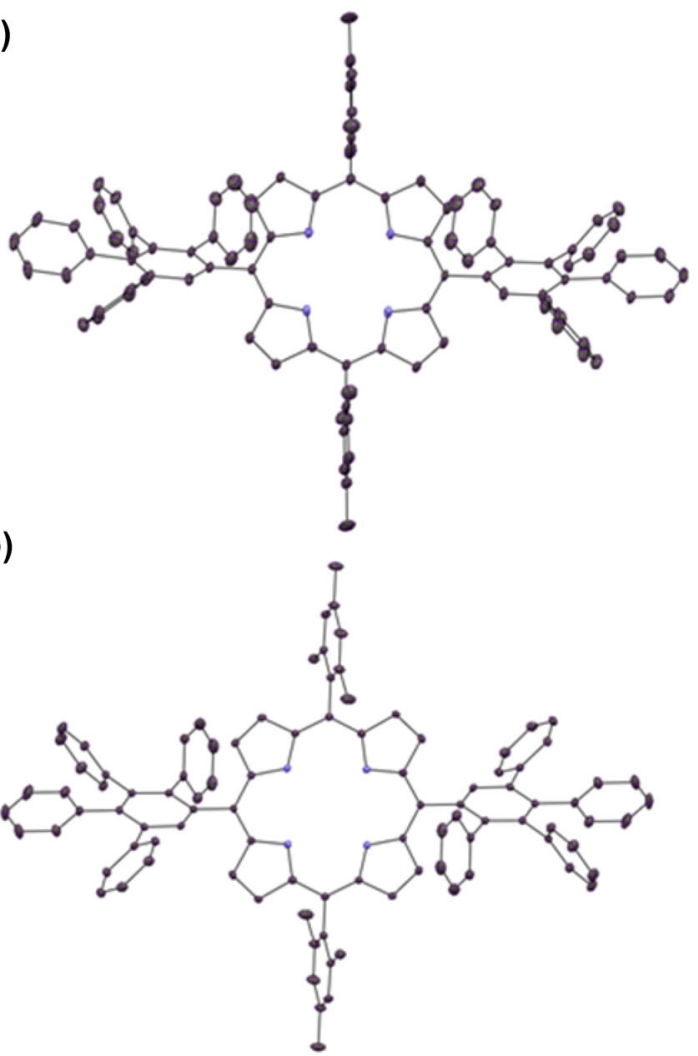

(c)

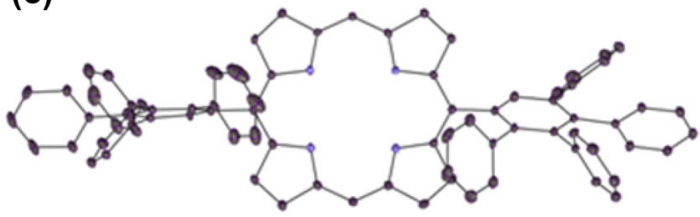

(d)

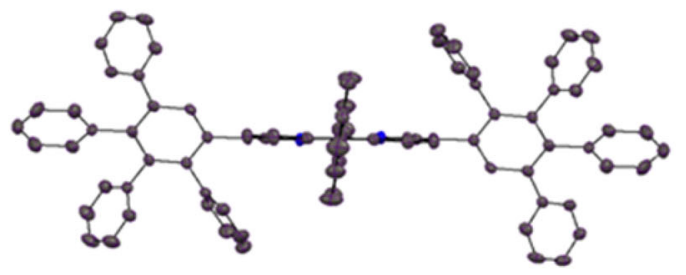

(e)

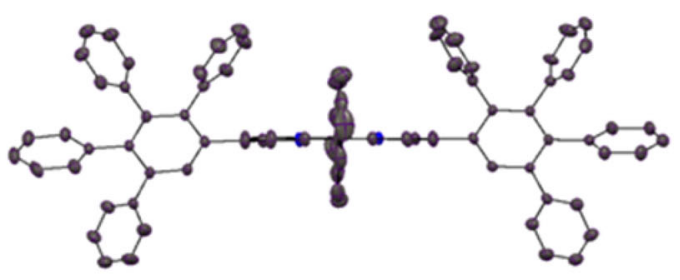

(f)

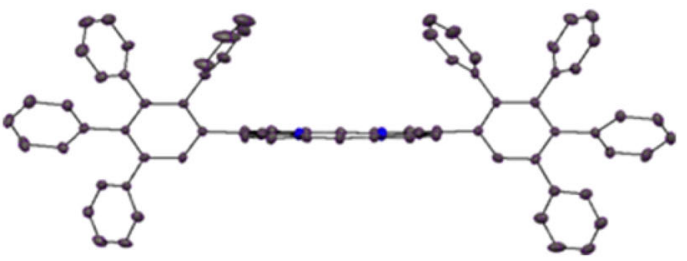

Figure 4. X-Ray crystal structures of trans-2a (a and c), cis-2a (b and d), and cis-3a (c and e). Thermal ellipsoids are drawn at the 50\% (trans-2a) and 15\% (cis-2a and cis-3a) probability levels. All hydrogen atoms are omitted for clarity.

of $\mathrm{MeOH} / \mathrm{CHCl}_{3}$ solutions. The structures for trans2a, cis-2a and cis-3a are presented in Figure 4. The porphyrin macrocycles are found to be almost planar despites two sterically hindered tetraphenylbenzene moieties in proximity to porphyrin macrocycle.

The unambiguous evidence of atropisomers trans2a and cis-2a had emerged from single crystal X-ray analysis (Figures $4 \mathrm{a}$ and $4 \mathrm{~b}$ ). These conformational isomers probably exist because of restricted rotation around $\mathrm{C}_{\text {meso }}-\mathrm{C}_{\mathrm{TPB}}$ bond between porphyrin and tetraphenylbenzene. The $\mathrm{C}_{\text {meso }}-\mathrm{C}_{\mathrm{TPB}}$ bond length in cis-2a is $1.514 \AA$ and $1.510 \AA$, and dihedral angles $(\Phi)$ between planes containing porphyrin and TPB are $77.18^{\circ}$ and $81.70^{\circ}$. In sharp contrast, the $\mathrm{C}_{\text {meso }}-\mathrm{C}_{\mathrm{TPB}}$ bond length on both sides of trans-2a is $1.499 \AA$ and dihedral angles $(\Phi)$ between planes containing porphyrin and TPB are $73.59^{\circ}$ and $73.59^{\circ}$. The summary of crystal parameters is presented in Table S1 (in Supplementary Information).

\subsection{Photophysical properties}

The photophysical properties of free-base porphyrins and their metal complexes have been investigated in dichloromethane. As anticipated, the trans-porphyrin and cis-porphyrin exhibited identical UV-Visible absorption and emission spectra (Figure 5). In comparison to tetraphenylporphyrin (TPP) ${ }^{13}$ the absorption $\lambda_{\max }$ for meso-mesityl substituted $\mathrm{A}_{2} \mathrm{~B}_{2}$ porphyrins (trans$\mathbf{2 a} / \mathbf{2 b}$ and $c i s-\mathbf{2 a / 2} \mathbf{b})$ are red-shifted, while the meso free porphyrin (cis-3a and cis-3b) showed blue-shifted absorption.

The fluorescence lifetime of cis-2a is longer than that of trans-2a and cis-3a (Table 1). It is noteworthy here to mention that the lifetimes of free base porphyrins are shorter than that of tetraphenyl porphyrin (TPP). This may be due to non-radiative losses via phenyl ring rotation. On the other hand, $\mathrm{Zn}(\mathrm{II})$-metallated porphyrins 

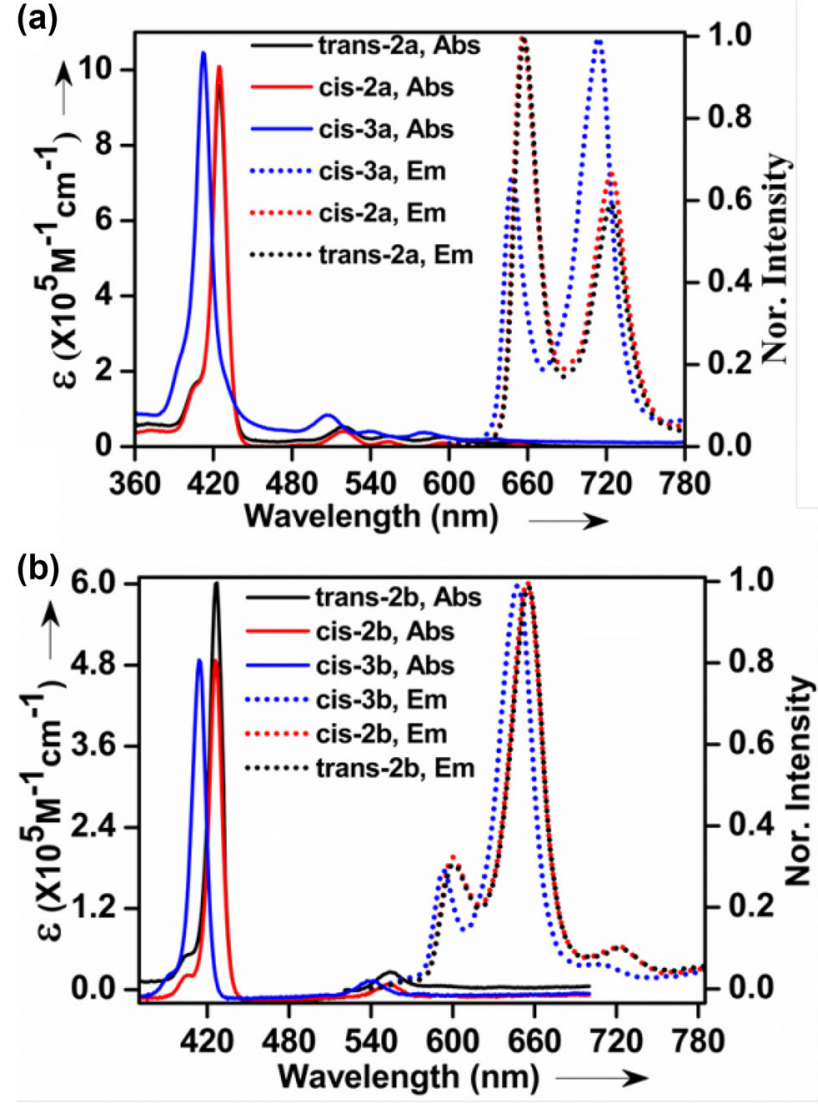

Figure 5. UV-vis (solid lines), emission spectra (dotted lines) for trans-2a, cis-2a, cis-3a (a) and trans-2b, cis-2b, cis-3b (b) recorded in $\mathrm{CH}_{2} \mathrm{Cl}_{2}$.

have longer lifetimes than $\mathrm{Zn}$ (TPP). The metallated complexes trans-2b, cis-2b and cis-3b exhibits similar trends as that of free bases in UV-visible and emission studies. In sharp contrast, the fluorescence lifetime of cis-3b is lesser than that of cis-2b and trans-2b. The summary of photophysical data is represented in Table 1.

\subsection{Electrochemical studies}

Cyclic and differential pulse voltammetric studies have been carried out in $\mathrm{CH}_{2} \mathrm{Cl}_{2}$ containing $0.1 \mathrm{M} \mathrm{TBAPF}_{6}$ against $\mathrm{Ag} / \mathrm{Ag}^{+}$electrode and the redox potentials are summarized in Table 2. The trans-2a and cis-2a isomers both exhibit two oxidation and one reduction waves at $1.32 \mathrm{~V}, 0.9 \mathrm{~V}$ and $-1.43 \mathrm{~V}$, respectively. These results suggest that the conformational difference does not lead to any noticeable electronic perturbation.

The zinc(II) metallated (trans-2b and cis-2b) TPBporphyrins have shown similar redox peaks as that of free-base porphyrin. However, the oxidation and reduction potentials were found to be modified compared to that of free-base porphyrin. The presence of electron donating mesityl group on cis- and trans-TPB porphyrins resulted cathodically shifted oxidation and reduction waves with respect to meso-free-porphyrin cis-3a and cis-3b (Figures S36-S37 in Supporting Information). The electrochemical HOMO-LUMO gaps are fairly consistent with the computed energy gaps (Table 2).

\subsection{Computational studies}

Density functional theory (DFT) and time-dependent DFT (TD-DFT) calculations were conducted for all the compounds by using B3LYP/6-31G(d) $(\mathrm{C}, \mathrm{H}, \mathrm{N})+$ LANL2DZ ( $\mathrm{Zn}$ ) level of theory. The Kohn-Sham frontier molecular orbital diagrams for all the compounds are presented in Figure 6. The distribution of electron density in degenerate pairs of HOMO and LUMO of free-base porphyrin and metallated porphyrin are delocalized only onto the $\pi$-system of the porphyrin as predicted by the Gouterman four orbitals model. Perpendicular arrangement of TPB with respect to mean plane of porphyrin macrocycle prevents $\pi$-extension to the meso-aryl substituents (Figure S39 in Supporting Information).

The excitation energies, oscillator strengths, and electronic configuration for all the compounds are listed in Tables S2-S7 (in Supporting Information). The simulated absorption spectra are in close agreement with

Table 1. Summary of absorption and emission data for free base and metallated TBP-porphyrin derivatives in $\mathrm{CH}_{2} \mathrm{Cl}_{2}$.

\begin{tabular}{|c|c|c|c|c|}
\hline Compd. & $\begin{array}{l}\text { Soret-band, } \lambda_{\max }, \mathbf{n m} \\
\left(\varepsilon / 10^{5}, \mathbf{M}^{-1} \mathbf{c m}^{-1}\right)\end{array}$ & Q-bands, $\lambda_{\max }, \mathbf{n m}\left(\boldsymbol{\varepsilon} / 10^{5}, \mathbf{M}^{-1} \mathbf{c m}^{-1}\right)$ & $\lambda_{\mathrm{em}}, \mathbf{n m}\left(\Phi_{\mathrm{fl}}\right)$ & $\tau_{\mathbf{f l},}, \mathbf{n s}$ \\
\hline trans-2a & $424(9.62)$ & $520(0.53), 552(0.28), 595(0.27), 652(0.133)$ & $657,724(0.20)$ & 9.42 \\
\hline cis-2a & $424(10.16)$ & $520(0.41), 552(0.14), 595(0.11), 652(0.08)$ & $657,724(0.20)$ & 9.52 \\
\hline cis-3a & $412(10.46)$ & $507(0.84), 539(0.41), 579(0.38), 634(0.22)$ & $635,702(0.13)$ & 9.44 \\
\hline trans-2b & $425(6.04)$ & $554(0.29)$ & $600,655(0.16)$ & 6.37 \\
\hline cis-2b & $425(4.87)$ & $554(0.12)$ & $600,655(0.15)$ & 6.12 \\
\hline cis-3b & $414(4.89)$ & $541(0.13)$ & $580,635(0.12)$ & 2.04 \\
\hline $\mathbf{T P P}^{13 a}$ & 417 & $513,548,589,646$ & $650,714(0.12)$ & 9.62 \\
\hline $\mathbf{Z n T P P}^{13 b}$ & 421 & 556,603 & $603,650(0.033)$ & 1.98 \\
\hline
\end{tabular}


Table 2. Summary of electrochemical potentials for free-base and metallated TBPporphyrin derivatives $v s \mathrm{Ag} / \mathrm{Ag}^{+}$.

\begin{tabular}{lccccc}
\hline Compd. & \multirow{2}{*}{$\mathbf{E}^{\text {ox2 }}(\mathbf{V})$} & $\mathbf{E}^{\text {ox1 }}(\mathbf{V})$ & $\mathbf{E}^{\text {red }}(\mathbf{V})$ & \multicolumn{2}{c}{ HOMO-LUMO gap $(\mathbf{e V})$} \\
\cline { 5 - 6 } & & & & $\mathbf{C V}$ & DFT \\
\hline trans-2a & 1.32 & 0.90 & -1.43 & 2.33 & 2.71 \\
cis-2a & 1.32 & 0.90 & -1.43 & 2.33 & 2.71 \\
cis-3a & 1.36 & 0.98 & -1.32 & 2.30 & 2.77 \\
trans-2b & 1.03 & 0.72 & -1.28 & 2.00 & 2.80 \\
cis-2b & 1.03 & 0.72 & -1.28 & 2.00 & 2.80 \\
cis-3b & 1.09 & 0.78 & -1.21 & 1.99 & 2.87 \\
TPP14a & & 1.02 & -1.20 & 2.22 & - \\
ZnTPP $14 b$ & & 0.78 & -1.39 & 2.17 & - \\
\hline
\end{tabular}

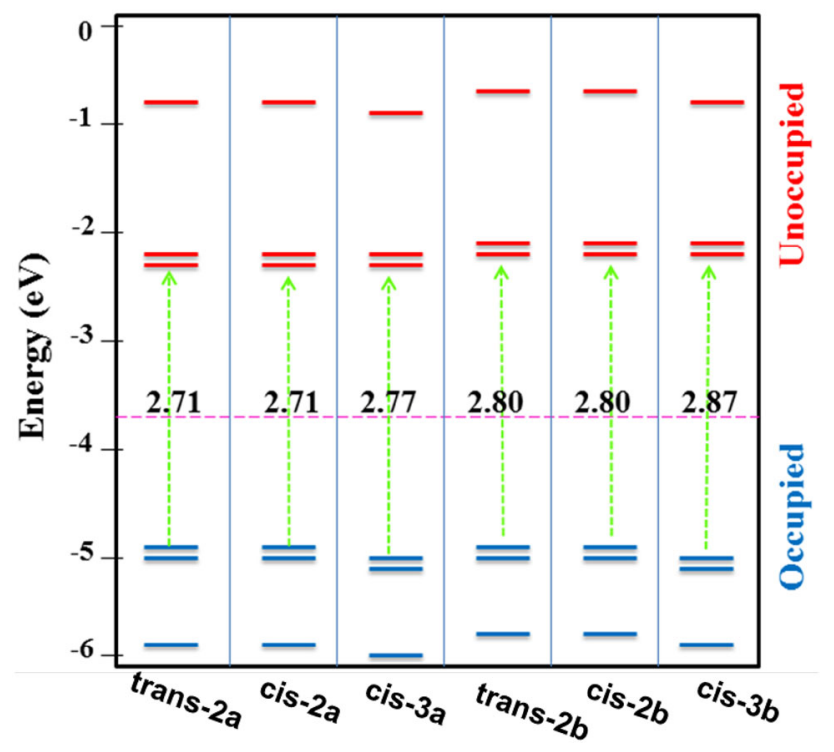

Figure 6. DFT-predicted orbital energies for free-base and metallated TBP-porphyrin derivatives calculated based on B3LYP/6-31G(d) (C,H,N) + LANL2DZ (Zn) level.

the experimental trend (Figures S40-S45 in Supporting Information). Time-dependent density functional theory calculations revealed significant contributions in vertical electronic transition from HOMO to LUMO, HOMO-1 to LUMO+1; HOMO-1 to LUMO, HOMO to $\mathrm{L}+1$ as shown in Tables S1-S6 (in Supporting Information).

\section{Conclusions}

In summary, closest-contact meso-Tetraphenylbenzene (TPB) substituted porphyrins have been designed and synthesized. Unlike pentaphenylbenzene substitution, these aryl groups present an unsymmetrical environment around the meso-positions. Due to this unsymmetrical substitution, the meso-mesityl TPB-porphyrins exhibit two discrete atropisomers trans-2a and cis-2a due to restricted rotation around $\mathrm{C}_{\text {meso }}-\mathrm{C}_{\mathrm{TPB}}$ bond. The photophysical and electrochemical properties of the synthesized hybrids have been investigated with respect to tetraphenylporphyrin (TPP) and tetraphenylporphyrinato zinc(II) (ZnTPP). Moreover, the redox potentials of the TPB conjugates are found to be sensitive to the meso-substituents. Therefore, this work opens up the possibility to investigate the applications of these novel atropisomers towards opto-electronic applications to understand the effect of structural isomerism. Achieving highly conjugated meso-meso directly linked and meso-meso triply fused dimers via oxidative coupling strategy is the main objective of our future work.

\section{Supplementary Information (SI)}

Details of synthesis, characterization, computational, photophysical and electrochemical studies are available in SI at www.ias.ac.in/chemsci.

\section{Acknowledgements}

We thank IISER Bhopal for infrastructure and Centre for Research on Environmental and Sustainable Technologies (CREST) [established under MHRD/FAST/2014020 scheme], New Delhi, for financial support.

\section{References}

1. (a) Hayashi S, Tanaka M, Hayashi H, Eu S, Umeyama T, Matano Y, Araki Y and Imahori H 2008 Naphthyl-Fused $\pi$-Elongated Porphyrins for Dye-Sensitized TiO_2 Cells J. Phys. Chem. C 112 15576; (b) Tanaka M, Hayashi S, Eu S, Umeyama T, Matano Y and Imahori H 2007 Novel Un-symmetrically $\pi$-Elongated Porphyrin for Dye-Sensitized TiO_2 Cells Chem. Commun. 2069

2. Sayyad M H, Saleem M, Karimov K S, Yaseen M, Ali M, Cheong K Y and Noor A F M 2010 Synthesis 
of $\mathrm{Zn}$ (II) 5,10,15,20-Tetrakis(4-isopropylphenyl) Porphyrin and Its Use as a Thin Film Sensor Appl. Phys. A: Mater. Sci. Process. 98103

3. Bonnett R 1995 Photosensitizers of the porphyrin and phthalocyanine series for photodynamic therapy Chem. Chem. Soc. Rev. 2419

4. (a) Aratani N, Kim D and Osuka A $2009 \pi$-Conjugation Enlargement toward the Creation of Multi-Porphyrinic Systems with Large Two-Photon Absorption Properties Chem. Asian J. 4 1172; (b) Calvete M, Yang G Y and Hanack M 2004 Porphyrins and phthalocyanines as materials for optical limiting Synth. Met. 141 231; (c) Fei H S, Han L, Ai X C, Yin R and Shen J C 1992 Reverse saturable absorption and third-order optical nonlinearity in porphyrin Chin. Sci. Bull. 37 298; (d) Senge M O, Fazekas M, Notaras E G A, Blau W J, Zawadzka M, Locos O B and Mhuircheartaigh E M 2007 Nonlinear Optical Properties of Porphyrins Adv. Mater. 192737

5. (a) Wu J, Pisula W and Müllen K 2007 Graphenes as Potential Material for Electronics Chem. Rev. 107 718; (b) Berresheim A J, Müller M and Müllen K 1999 Polyphenylene Nanostructures Chem. Rev. 99 1747; (c) Screen T E O, Blake I M, Rees L H, Clegg W, Borwick S J and Anderson H L 2002 Making Conjugated Connections to Porphyrins: A Comparison of Alkyne, Alkene, Imine and Azo Links J. Chem. Soc., Perkin Trans. 1 320

6. Lewtak J P and Gryko D T 2012 Synthesis of $\pi$ Extended Porphyrins via Intramolecular Oxidative Coupling Chem. Commun. 4810069

7. (a) Kurotobi K, Kim K S, Noh S B, Kim D and Osuka A 2006 A Quadruply Azulene-Fused Porphyrin with Intense near-IR Absorption and a Large TwoPhoton Absorption Cross Section Angew. Chem. Int. Ed. 45 3944; (b) Shen D M, Liu C and Chen Q Y 2006 A General and Efficient Palladium-Catalyzed Intramolecular Cyclization Reaction of $\beta$-Brominated Porphyrins J. Org. Chem. 71 6508; (c) Cammidge A N, Scaife P J, Berber G and Hughes D L 2005 Cofacial Porphyrin-Ferrocene Dyads and a New Class of Conjugated Porphyrin Org. Lett. 27 3413; (d) Yamane O, Sugiura K, Miyasaka H, Nakamura K, Fujimoto T, Nakamura K, Kaneda T, Sakata Y and Yamashita M 2004 Pyrene-Fused Porphyrins: Annulation Reactions of meso-Pyrenylporphyrins Chem. Lett. 33 40; (e) Diev V V, Hanson K, Zimmerman J D, Forrest S R and Thompson M E 2010 Fused Pyrene-Diporphyrins: Shifting near-Infrared Absorption to $1.5 \mu \mathrm{m}$ and beyond Angew. Chem. Int. Ed 49 5523; (f) Myśliwiec D, Donnio B, Chmielewski P J, Heinrich B and Stepień M Peripherally Fused Porphyrins via the Scholl Reaction: Synthesis, Self-Assembly and Mesomorphism J. Am. Chem. Soc. 1344822

8. (a) Davis N K S, Pawlicki M and Anderson H L 2008 Expanding the Porphyrin $\pi$-System by Fusion with
Anthracene Org. Lett. 103945 ; (b) Davis N K S, Thompson A L and Anderson H L 2010 Bis-Anthracene Fused Porphyrins: Synthesis, Crystal Structure, and near-IR Absorption Org. Lett. 122124

9. (a) Englert J M, Malig J, Zamolo V A, Hirsch A and Jux N 2013 HBC-Porphyrin-Close Contact Chromophores Chem. Commun. 494827; (b) Lungerich D, Hitzenberger J F, Marcia M, Hampel F, Drewello T and Jux N 2014 Superbenzene-Porphyrin Conjugates Angew. Chem. Int. Ed. 5312231

10. (a) Aratani $\mathrm{N}$ and Osuka A 2012 A meso-meso directly linked octameric porphyrin square Chem. Commun. 4067; (b) Diev V V, Schlenker C W, Hanson K, Zhong Q, Zimmerman J D, Forrest S R and Thompson M E 2012 Porphyrins Fused with Unactivated Polycyclic Aromatic Hydrocarbons J. Org. Chem. 77 143; (c) Ota K, Tanaka T, Osuka A 2014 meso- $\beta$ Dibenzo[a,g]corannulene-Fused Porphyrins Org. Lett. 16 2974; (d) Jiao C, Huang K W, Guan Z, Xu Q H and Wu J 2010 N-Annulated Perylene Fused Porphyrins with Enhanced near-IR Absorption and Emission Org. Lett. 124046

11. (a) Lee C H and Lindsey J S 1994 One-flask synthesis of meso-substituted dipyrromethanes and their application in the synthesis of trans-substituted porphyrin building blocks Tetrahedron 50 11427; (b) Lindsey J S 2010 Synthetic Routes to meso-Patterned Porphyrins Acc. Chem. Res. 43 300; (c) Crossley M J, Field L D, Forster A J, Harding M M and Sternhell S 1987 Steric Effects on Atropisomerism in Tetraarylporphyrins J. Am. Chem. Soc. 109 341; (d) Gunther M J and Mander 1981 L $\mathrm{N}$ Synthesis and Atropisomer Separation of Porphyrin Containing Functionalization at the 5,15-meso Positions: Application to the Synthesis of Binuclear Ligand Systems J. Org. Chem. 464792

12. Nguyen $\mathrm{H} \mathrm{V}$, Yeamine $\mathrm{M} \mathrm{R}$, Amin $\mathrm{J}$, Motevalli $M$ and Richards C J 2008 Synthesis and ${ }^{1} \mathrm{H}$ NMR spectro-scopic properties of substituted $\left(\eta^{4}\right.$ tetraarylcyclobutadiene $)\left(\eta^{5}\right.$-cyclopentadienyl) cobalt metallocenes J. Organomet. Chem. 6933668

13. (a) Owens J W, Smith R, Robinson R and Robins M 1998 Photophysical Properties of Porphyrins, Phthalocyanines, and Benzochlorins Inorg. Chim. Acta 279 226; (b) Rochford J, Botchway S, McGarvey J J, Rooney A D and Pryce M T Photophysical and Electrochemical Properties of meso-Substituted Thien-2-yl Zn(II) Porphyrins J. Phys. Chem. A 11211611

14. (a) Kadish K M and Morrison M M 1997 Solvent and Substituent Effects on the Redox Reactions of ParaSubstituted Tetraphenylporphyrin J. Am. Chem. Soc. 98 3326; (b) D'Souza F, Zandler M E, Tagliatesta P, Ou Z, Shao J, Van Caemelbecke E and Kadish K M 1998 Electronic, Spectral, and Electrochemical Properties of $\left(\mathrm{TPPBr} \_x\right) \mathrm{Zn}$ Where TPPBr$\_x$ is the Dianion of $\beta$ Brominated-Pyrrole Tetraphenylporphyrin and $\mathrm{x}$ Varies from 0 to 8 Inorg. Chem. 374567 